\title{
Taoism: Eastern Message of Non-Duality
}

\author{
Danylova Tetiana \\ National University of Life and Environmental Sciences of Ukraine, \\ Department of Philosophy, PhD in Philosophy, Associate Professor, Ukraine
}

\begin{abstract}
Taoist thinkers interpret existence as a continuous process. The source of changes is not an external force, but a tendency for transformation inherent in the Universe. In the world limited by space, time, and causation, in the world of distinctions and oppositions, Taoist practitioners achieve freedom of the mind and go beyond such a distinction. A new worldview without preferences towards any binary opposition is formed. Taoists obtain true knowledge of the world and develop complete awareness of infinity and diversity of life. This paper aims to analyze the key concepts of Taoism.
\end{abstract}

Keywords: Taoism; Tao; Qi; Wu Wei; binary oppositions; non-duality; reality.

UDC 111.1:140.8

LCC Subject Category: B5800-5802,

BL1899-1942.85

DOI: http://dx.doi.org/10.22178/pos.16-7

\section{Introduction}

Nowadays, the spiritual heritage of the East has attracted attention and considerable interest. Taoism as a complete philosophical system that includes three relatively autonomous, but deeply interconnected levels - religious doctrine, philosophical discourse, and psycho-techniques - is becoming increasingly popular in the Western countries. Taoism is perhaps the only one religious and philosophical system that encourages its adherents to live a happy, long, healthy life in this (not in the transcendent) world. For Taoists life is the highest value. According to some researchers [4; 5], Taoism has contributed to the development of science and medicine in China. Many herbs, minerals were discovered in the search for extraordinary means to prolong life or achieve immortality. Taiwanese say: "Confucianism is a food store, Buddhism is a department store, and Taoism is a drug store". Taoist practices of physical and spiritual healing, universal human development are well known outside of China. Some of them are Tai Chi Chuan, Hsing-i Chuan, Bagua Zhang, Qigong, internal alchemy, meditation, breathing techniques, which are mastered by more and more people. Many Eastern spiritual traditions claim that the true nature of reality is non-dual. All binary oppositions are either unrealistic or inaccurate description, which is used to simplify an interpretation of the world. For example, Buddhist schools teach that the individual "I" does not exist. Dual- ity "subject - object" is an illusion. Mental images of things and emptiness are inseparable. Humans have to go beyond the dual thinking to perceive the true nature of their minds. They are usually preoccupied with the concepts of duality; however, pure mind is not prone to this error. Mental phenomena appear and disappear, but basically, they are empty. A mind cannot exist in external phenomena, which are constantly changing. Thus, Eastern sages say that mind is empty. This emptiness is seen as clear light. All concepts of duality dissolve into this awareness [2].

\section{Result and Discussion}

Taoism can be seen as is a tradition of nonduality. It is not based on logical analysis, it is rather the antipode of logic with its dualistic way of thinking. It has nothing to do with any assertion or negation: assertions include the opposite element and cannot exist without it, and vice versa. Taoism seeks to understand the world in its non-duality. It aims at awakening our souls and our awareness of the true basis of life.

In Taoist tradition, the concept of Yin and Yang, which is often misinterpreted as a symbol of duality, in fact, expresses the idea that all apparent opposites are complementary parts of One whole [3]. During meditation, Taoists are immersed into their inner world to understand the rhythms of the universe. Yin and Yang transform into each 
other [8]. There is neither beginning nor end, there is only the way to go. The purpose of life in Taoism is a return to the eternal root. The one, who understood the essence of transformation, has become enlightened.

The basis of the Taoist worldview is one unified pulsating Cosmos and all its manifestations. The world was not created by God. It created itself out of its own potential existence. Cosmos is the only God. Taoist world is not split into the eternal spirit and temporarily existing matter.

The core of the Taoist worldview is neither matter nor consciousness, but life energy called Qi (Ki, Chi). Qi is the vital force that gives life to all forms of the Universe. It is a vibrating component of existence, continuous flow of life at the molecular, atomic, and sub-atomic levels. Everything that exists in the world is Qi and its states. Qi is a grand vital force that permeates the whole Cosmos, in fact, it is Cosmos itself. Everything exists due to its transformation: as water becomes steam or ice, so condensing Qi becomes matter and rarefying Qi becomes spirit. Ontology of Taoism is an ontology of processes. It is not the ontology of things since everything appears to be a process. Thus, there is no insurmountable boundary between matter and spirit: they are different modes of one unified Qi. The laws of Qi circulation are the same for both Cosmos and the human body. On our planet, it moves along the meridians, which are called "dragon veins (lines)". In the places where the meridian comes close to the surface of the earth, the soil is fertile and the climate is favourable for life. In those places where Qi energy is low, the land is like a desert. In the human body, Qi circulates along the energy channels filling them with life. The hidden basis of any disease is a violation of the free flow of Qi. The experienced physicians can recover it. Traditional Chinese medicine is closely associated with the practice of Taoism. Humans are born with a store of Qi energy, which is called Prenatal Qi. This "original" energy is depleted over the years, which leads to ageing and death. Qi that people accumulate during their daily life comes from the air they breathe, food they eat, special practices (Qigong, Tai Chi Chuan, meditation). The replenishment of Prenatal Qi by Postnatal is one of the main goals of Taoist practices. Practitioners strive to change their bodies and minds, get rid of the usual limits of physicality and spirituality, establish their "bodies of light", and achieve immortality.
Tao is the universal way, the highest norm of Cosmos and human society. Tao may be interpreted as the Universe in the flow of formation or as the essence/model of Nature that gives order and balance to the world. Taoism is the concept of non-duality. Tao is one unified whole that originates all the elements of the Universe. Through the lens of Tao antinomy of good-andevil disappears, since good and evil are relative: they define each other and make no sense without each other. Good is good only in relation to evil.

When the world knows beauty as beauty, ugliness arises

When it knows good as good, evil arises

Thus being and non-being produce each other

Difficult and easy bring about each other

Long and short reveal each other

High and low support each other

Music and voice harmonize each other

Front and back follow each other [7].

Tao is devoid of form and content, but all its actions are harmonious. Harmony means how Tao creates, maintains, restores and renews itself in its eternal fullness. Since the actions of Tao are formless, its highest harmony is in itself - where nothing is created and nothing is disappeared. Tao is constantly in its fullness, integrity, and completeness. Tao is always identical to itself, it is determined by its own nature.

Humans follow the laws of Earth

Earth follows the laws of Heaven

Heaven follows the laws of Tao

Tao follows the laws of nature [7].

Tao manifests itself in the relationship between $\mathrm{Wu}$ Chi and Yin - Yang. The basis of all things is the Great Void, which has no phenomenal manifestations. The ancient Chinese called it $\mathrm{Wu}$ Chi (Infinite, Unlimited, Boundless). Heaven and Earth were not formed, the universe was in the state of primordial Chaos (Hun Tun), Yin and Yang have not yet arisen, and Qi was an organic whole. Wu Chi is an absolutely simple, unformed, indivisible, it is Absence ( $\mathrm{Wu}$ ) or Absence of $\mathrm{Ab}$ sence (Wu Wu). It can be illustrated by an empty circle. Lao Tzu characterised this state as inexhaustible Tao. 
Know the white, hold to the black

Be the standard of the world

Being the standard of the world

The eternal virtue does not deviate

Return to the state of the boundless [7].

Wu Chi gives life to Tai Chi, Tai Chi transforms and generates Yang. Yang reaches the top and becomes Yin. Yin in accordance with the similar algorithm becomes Yang. The world is polarised: there are positive charges (Yang) and negative charges (Yin). Yang is conceived of as active, light, heat, vertical lines, mountains, male. Yin is conceived of as passive, dark, cold, horizontal lines, water, female. This state of Qi is the Supreme Ultimate (Tai Chi), which is graphically depicted as a famous Monad - a circle that consists of white and black drop-shaped halves with the dots of the opposite colours inside them.

The mutual transformation of Yin and Yang includes five phases, which in accordance with a long-standing tradition were called "The Five Elements" - Wu Xing. "The alternation and combination of yang and yin generate water, fire, wood, metal, and earth. With these five [phases of] Qi harmoniously arranged, the Four Seasons proceed through them" [10]. The Wood element is young Yang, it generates Fire. The Fire element is mature Yang, it generates Earth. The Earth element is a balance of Yin and Yang, it gives life to Metal. The Metal element is young Yin. It is the source of Water, which means mature Yin. Water, in turn, creates Wood again. This order of creation is called a generating/creative cycle. The opposite direction - Wood - Water - Metal - Earth - Fire is an exhausting/weakening cycle. Wood absorbs Water; Water weakens Metal; Metal is taken from Earth; Earth snuffs Fire; Fire burns Wood. In the destructive cycle, five elements destroy one another: Water extinguishes Fire; Fire melts Metal; Metal cuts into Wood; Wood destroys Earth; Earth muddies Water. Knowledge of these principles of transformation is the key to the art of Feng Shui. Each of the Five Elements is a kind of a marker for the various spheres of life. Wood symbolises the East, spring, green colour, dragon, humanity, liver. Fire is the South, hot summer, red phoenix, ritual, awe, heart. Earth is perceived as a centre, off-season, yellow colour, unicorn, sincerity, trust, spleen. Metal is associated with the West, autumn period, white colour, tiger, justice, lungs. Water is related to the North, winter, black colour, turtle, wisdom, kidneys. The
Five Elements are just Yin and Yang, Yin and Yang are the Supreme Ultimate, and the Supreme Ultimate is generated by Infinite. Taoist thinkers believed that this endless process of interaction and transformation of the two principles created three worlds: the world of Heaven - the world of Human - the world of Earth [9].

Human beings, like all that exists, depend on Tao. When they are in harmony with the universal cosmic law, their life is long and happy. It becomes possible if they follow the principle of $\mathrm{Wu}$ Wei. Wu Wei is the special kind of "joining the flow of existence", merging of the individual "I" and Qi, a unity of subject and object.

\section{Bearing it, rearing it}

Bearing without possession

Achieving without arrogance

Raising without domination

This is called the Mystic Virtue [7].

There is neither active "I" nor object that requires efforts. The boundary between subject and object disappears. There is just a spontaneous act according to Tao-Way.

Being in $\mathrm{Wu}$ Wei state, humans achieve inner balance and harmony, obtain invisible soft power. When they live in accordance with Tao the rhythms of Cosmos - their actions become effortless and natural. They are aware of their place in the world, their involvement in all that exists [6]. They are "dissolved" in the flow of Tao.

Feeling their oneness with all that exists, people do not perceive this world as hostile, do not split it into familiar, friendly Cosmos and dangerous Chaos. Anxiety, fear, and tension become less important and not so unbearable [1]. Humans understand that life and death, good and evil, spirit and matter are two different aspects of the same Tao-Unity. They feel an unusual silence of the mind. In this silence (or void) the sources of all activities are at rest. This is a state of pure existence - the initial form of human existence.

\section{Conclusions}

Thus, in the world limited by space, time, and causation, in the world of distinctions and oppositions, Taoist practitioners achieve freedom of the mind and go beyond such a distinction. A new worldview without preferences towards any bi- 
nary opposition is formed. Taoists obtain true knowledge of the world and develop complete awareness of infinity and diversity of life.

Taoist doctrine can be used as a guide to a happy human life. The great value of Taoism lies in the ability to direct humans to self-exploration, self- development, transformation, which makes it possible to connect with both their true nature and the universe. Taoist practices help to understand how to achieve this state of unity, harmony, and balance with Tao.

\section{References}

1. Danylova, T. (2014). Overcoming the Antinomies of Human Existence: Ontology of Trickster. Anthropological Measurements of Philosophical Research, 6, 17-23.

2. Danylova, T. (2014). The World without Fear and Illusions: Meditation as a Means of Overcoming Binary oppositions of Culture. International Researchers, 3(2), 79-82.

3. Ericson, P., \& Murphy, L. (2013). A History of Anthropological Theory (4th ed.). Toronto: University of Toronto Press Higher Education.

4. Li, Y.-S. (2005). A New Interpretation of Chinese Taoist Philosophy : an anthropological / psychological view. London: Taoist Recovery Centre.

5. Needham, J. (1959). Science and Civilization in China. Volume 3. Mathematics and the Sciences of the Heavens and the Earth. Cambridge: Cambridge University Press.

6. Salata, G. (2012). Human Nature in the Problem Field of Cultural Anthropology. Ural Research Bulletin, 1, 17-23.

7. Laozi. (2006). Tao Te Ching: Annotated \& Explained. (D. Lin, Trans.). Woodstock: SkyLight Paths Pub.

8. Wang, R. (2012). Yinyang: The Way of Heaven and Earth in Chinese Thought and Culture. Cambridge: Cambridge University Press.

9. Chung-Lu, Ch. (2005). Tao of Health, Longevity, and Immortality: The Teachings of Immortals Chung and Lu. (E. Wong, Trans). Boston: Shambhala.

10. Zhou Dunyi. (2009). Explanation of the Supreme Polarity Diagram (Taijitu shuo). (J. A. Adler, Trans). Retrieved from http://www2.kenyon.edu/Depts/Religion/Fac/Adler/Writings/TJTS-Zhu.pdf

(C) T. Danylova

Received 2016-11-13, Accepted 2016-11-19, Published online 2016-11-20 


\title{
Даосизм: восточная теория отсутствия двойственности
}

\author{
Данилова Татьяна Данилова \\ Национальный университет биоресурсов и природопользования Украины, \\ кафедра философии, кандидат философских науки, доцент, Украина
}

\begin{abstract}
Аннотация. Даосские мыслители интерпретируют существование как непрерывный процесс. Источником изменений является не внешняя сила, а тенденция к трансформации, присущая Вселенной. В мире, ограниченном пространством, временем и причинно-следственными связями, в мире различий и оппозиций, даосские практики достигают свободы разума и выходят за рамки таких различий. Формируется новый взгляд на мир без преимуществ по отношению к любой бинарной оппозиции. Даосские мыслители получают истинное знание о мире и развивают полную осведомленность 0 бесконечности и разнообразии жизни. Целью данной статьи является анализ ключевых понятий даосизма.
\end{abstract}

Ключевые слова: даосизм; Дао; Ци; У-вей; бинарная оппозиция; недвойственность; реальность.

\section{удК 111.1:140.8}

LCC Subject Category: B5800-5802,

BL1899-1942.85

DOI: http://dx.doi.org/10.22178/pos.16-7

\section{Список информационных источников}

1. Danylova T. Overcoming the Antinomies of Human Existence: Ontology of Trickster. Anthropological Measurements of Philosophical Research. 2014. № 6. C. 17-23.

2. Danylova T. The World without Fear and Illusions: Meditation as a Means of Overcoming Binary oppositions of Culture. International Researchers. 2014. № 3(2). C. 79-82.

3. Ericson P., Murphy L. A History of Anthropological Theory. 4th ed. Toronto : University of Toronto Press Higher Education, 2013. 273 p.

4. Li Y.-S. A New Interpretation of Chinese Taoist Philosophy : an anthropological / psychological view. London : Taoist Recovery Centre, 2005. 244 p.

5. Needham J. Science and Civilization in China. Volume 3. Mathematics and the Sciences of the Heavens and the Earth. Cambridge : Cambridge University Press, 1959. 877 p.

6. Salata G. Human Nature in the Problem Field of Cultural Anthropology. Ural Research Bulletin. 2012. № 1. P. 17-23.

7. Laozi. Tao Te Ching: Annotated \& Explained / trans. D. Lin. Woodstock : SkyLight Paths Pub., 2006. $169 \mathrm{p}$.

8. Wang R. Yinyang: The Way of Heaven and Earth in Chinese Thought and Culture. Cambridge : Cambridge University Press, 2012. 250 p.

9. Chung-Lu Ch. Tao of Health, Longevity, and Immortality: The Teachings of Immortals Chung and Lu / trans. E. Wong. Boston : Shambhala, 2005. 149 p.

10. Zhou Dunyi. Explanation of the Supreme Polarity Diagram (Taijitu shuo) / trans. J. A. Adler. Kenyon College. URL: http://www2.kenyon.edu/Depts/Religion/Fac/Adler/Writings/TJTS-Zhu.pdf (viewed 10.11.2016).

(C) Т. Данилова

Статья получена 13.11.2016, принята 19.11.2016, опубликована оnline 20.11.2016 